\title{
Sustainability Challenges in TAPERA Program
}

\author{
Towaf Totok Irawan ${ }^{1}$, Dicky Firmansyah ${ }^{2}$ \\ \{towaf@unpak.ac.id ${ }^{1}$, dicky.firmansyah@unpak.ac.id ${ }^{2}$ \} \\ Economic Faculty of Pakuan University, Tegallega, Bogor, West Java ${ }^{12}$
}

\begin{abstract}
TAPERA is a housing finance program through the fertilization and utilization of community funds which are used for the construction and improvement of community housing in a sustainable manner. Since TAPERA is a long-term program, one of the important issues is sustainability. The purpose of this study was to analyze the challenges of the sustainability of the TAPERA Program as indicated by the financial position (surplus or deficit) and queue of participants. Projection of the sustainability of the program is carried out through simulations adapted from the model developed by the Directorate of Housing Financing Team, Ministry of Public Works and Public Housing of the Republic of Indonesia. The study results show that the critical number of TAPERA funds is mainly influenced by the allocation of fertilization and utilization. Based on the simulation of a sustainable program, an optimistic scenario is applied with an allocation of $65 \%$ utilization and 35\% fertilization. On the other hand, the growth in the number of participants in the queue (waiting list for TAPERA benefits) is above the growth in the number of beneficiaries. This is a burden for TAPERA in the future. Under these conditions, the policies that must be considered are adjustments to the level of savings and subsidies for participants.
\end{abstract}

Keywords: TAPERA, Fertilization, Utilization, Allocation.

\section{Introduction}

Housing is one of the basic needs for the community, including lowincome people $(M B R)$. For the $M B R$ community, home ownership is a problem, most of which are in accordance with the ability to buy. $M B R$ which causes access to housing is increasingly limited. Issues related to low-income people (MBR) access to affordable housing has exercised in the following studies: [1]; [2]; [3]; [4]; [5]; [6]; [7]; [8]; [9]; [10]; and [11].

Issues such as this increase the non-revocation of strategies that can lead to an increasingly large backlog, namely involving the provision of housing and growing demand. At present the housing backlog has reached approximately 15 million, with an average annual rate of 800 thousand units. In an effort to encourage this backlog, the government and the Parliament gave a breakthrough by issuing [12] concerning Community Housing Savings (TAPERA). The main purpose of Tapera is to collect and provide long-term and low-cost funds needed 
for housing, to meet the needs of decent and affordable households for participants, especially those who are in the $M B R$ group.

Funds collected in TAPERA are allocated in 3 schemes, namely fertilization, utilization, and reserves. The allocation must be determined under the following : (1) existing regulation in Indonesia. In accordance with the TAPERA Law, those who will be TAPERA participants are all Indonesian citizens working in Indonesia who have the minimum wage. In this regard, it is necessary to understand how workers in Indonesia will become TAPERA participants; (2) based on a mature assessment in order to optimize the utilization of TAPERA funds collected from the community. This will be related to the critical allocation of TAPERA funds, also to any conditions that affect the calculation of the allocation of TAPERA funds. In addition, as TAPERA is a long-term program, policy makers must also pay attention to aspects of sustainability so that TAPERA funds are maintained and can provide maximum benefits.

To get an overview of the optimization of the TAPERA fund allocation, a calculation that provide projected optimization of TAPERA funds is needed through a simulation calculation by adapting the simulation model that has been prepared previously.

\section{Literature Review}

As mandated by [13] for the mobilization and fertilization of funds there is a need for housing savings as stipulated in the law. The mandate was then followed up with the issuance of [12] concerning Community Housing Savings. In this law it is stated that every worker and self-employed who earns at least the minimum wage must be a TAPERA participant (article 7). This article can be interpreted, without exception, that all Indonesian people who have worked must become TAPERA participants. Especially for self-employed workers, even though those earning below the minimum wage can become Tapera participants. In Article 7 paragraph (3), TAPERA participants are at least 20 years old or are married when registering.

As confirmed in [12], that the funds raised from TAPERA participants need to be funded by TAPERA to increase TAPERA funds, which use conventional or sharia principles. The application of TAPERA funds with conventional principles can be invested in instruments: bank deposits; central government debt securities; local government debt securities; securities in the field of housing and residential areas; other forms of investment that are safe and profitable in accordance with statutory provisions. Whereas the fertilization 
of funds using sharia principles can be invested in investment instruments such as: Islamic banking deposits; central government debt securities (SUKUK); local government debt securities $(S U K U K)$; sharia securities in the housing and settlement area; and / or other safe and profitable forms of investment in accordance with statutory provisions.

After TAPERA funds continue to be fostered to increase the value of TAPERA funds, then the TAPERA funds are used to finance housing for TAPERA participants. This housing finance is carried out by a bank or finance company (article 24 paragraph 3 ). This housing finance is only intended to finance housing ownership, house construction or house repairs, provided that it is the first house, only given once and the amount of value varies for each housing finance.

In [14] referred to as manpower is every person who is able to do work to produce goods and / or services both to meet their own needs and for the community. While what is meant by workers in this Law is every person who works by receiving wages or other forms of compensation. In [15] on Wages is known by two terms namely wages and non-wage income. Wages consist of components (i) wages without benefits; (ii) basic wages and fixed benefits; and (iii) basic wages, fixed allowances and non-permanent benefits. This wage is regulated in a work agreement, company regulations, or collective labor agreement (article 5, paragraph 4). Included in the non-wage income provisions are religious holiday allowances, bonuses, money to replace work facilities and service fees for certain businesses.

As stated in [12] above that Tapera funds can be invested in government bonds such as $S B N$ or $S B S N$. $S B N$ is Government Securities ( $S U N)$ and Government Sharia Securities $(S B S N)$ [16] concerning the Second Amendment to Bank Indonesia Regulation Number 10/13 / PBI / 2008 concerning Securities Auction and Administration of Securities Country). Government Securities $(S U N)$ are securities in the form of debt instruments denominated in rupiah and foreign currencies that are guaranteed payment of interest and principal by the Republic of Indonesia, in accordance with their period of validity. In accordance with Law No. 24 of 2002, SUN consists of Treasury Bills $(S P N)$ and Government Bonds (including Retail Government Bonds / ORI). SUN consists of Government Bonds (ON), Treasury Bills $(S P N)$, and Indonesian Retail Bonds (ORI). SUN has a validity period.

$S B S N$ or can be called a State $S U K U K$, is $S B N$ issued based on sharia principles, as evidence of the investment in $S B S N$ assets, both in Rupiah and foreign currencies (Bank Indonesia Regulation No.17 / 19 / PBI / 2015 concerning Second Amendment to Regulations Bank Indonesia Number 10/13 / PBI / 2008 concerning Government Securities Auction and Administration). 
[12] concerning Community Housing Savings (TAPERA), the application of TAPERA Funds is conducted to increase the value of the TAPERA Fund. This fertilization can be done with conventional or sharia principles. Investment instruments in the form of financial products with conventional principles can be in the form of: (1) bank deposits; (2) central government debt securities; (3) local government debt securities; (4) securities in the housing and settlement area; and / or (5) other safe and profitable forms of investment in accordance with statutory provisions.

Similar to conventional, investment instruments in the form of financial products with sharia principles are: (1) Islamic banking deposits; (2) central government debt securities $(S U K U K)$; (3) local government debt securities $(S U K U K)$; (4) Islamic securities in the housing and settlement area; and / or (5) other safe and profitable forms of investment in accordance with statutory provisions. The law also stipulates that TAPERA participants can choose the principle of fund fertilization in accordance with conventional principles or sharia principles. Further provisions regarding the mechanism and level of yield of the TAPERA Fund fertilization are regulated in a Government Regulation.

In the context of this fertilization, BP TAPERA appoints Investment Managers to invest in safe and profitable investment instruments, in accordance with statutory provisions. In the process, the Investment Manager subsequently enters into a collective investment contract with the Custodian Bank.

The results of the TAPERA Fund fertilization are used to utilize, reserve and cover BP Tapera's operational costs (if there is a shortage of the results of initial capital management).

In the explanation of [12] concerning TAPERA, fertilization is defined as an effort to provide added value to the TAPERA Fund through investment. Investment is an effort to get the value (financial benefits) of the assets controlled by placing all or part of the assets in one or more instruments (in the form of financial and non-financial products) with their respective characteristics (potential benefits, risks, and various terms and conditions).

[17] investment management (which can also be referred to as portfolio management or money management). Stages and processes in Investment Management are: (1) Determine the objectives (objectives) of the investment; (2) Establish investment policy lines; (3) Formulating an investment strategy; (4) Selecting investment instruments; and (5) Measuring and evaluating investment performance.

According to [12] that this housing finance is carried out by a bank or finance company (article 24 paragraph 3). This housing finance is only intended for use to finance housing ownership, house construction or home improvement, 
provided that it is the first house, only given once and the amount of value varies for each housing finance.

Reserve funds are funds set aside to accommodate needs that require relatively large funds that cannot be fulfilled in one fiscal year. Reserve funds are detailed according to the purpose of their formation. The formation of these reserve funds must be based on careful planning, so that the objectives and allocations are clear. For the establishment of a reserve fund, it must be stipulated in a government regulation which includes setting objectives for establishing a reserve fund, programs and activities to be funded from the reserve fund, the amount and annual details of the reserve fund that must be budgeted and transferred to the reserve fund account, the source of the reserve fund, and the fiscal year. implementation of reserve funds.

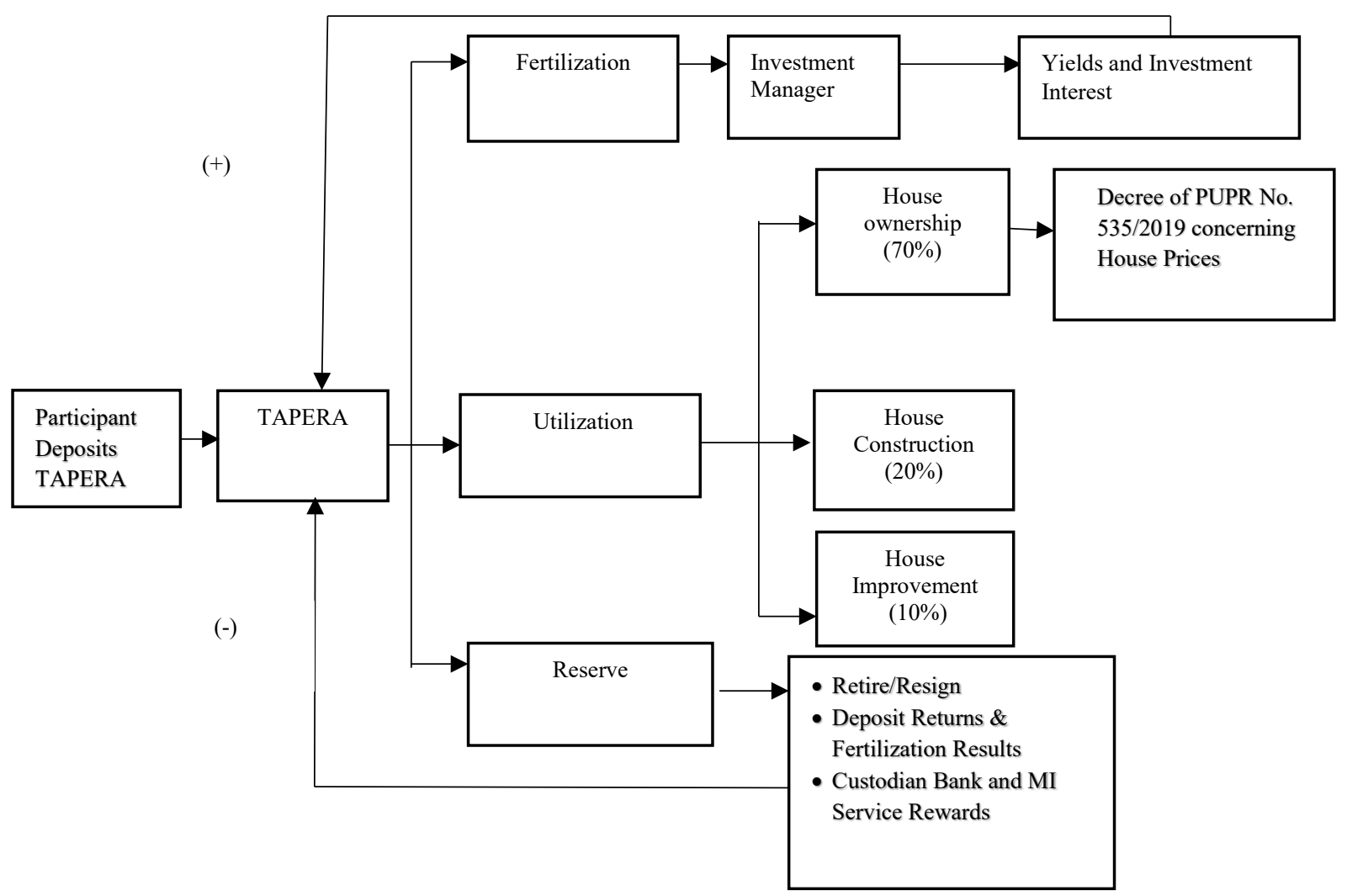

Figure 1. Framework for TAPERA Fund Allocation Study 


\section{Methodology}

This study analyze sustainability challenges in TAPERA Program that indicated by financial position (surplus or deficit) and participant's queue. This study projected critical figures of TAPERA allocation policy that will meet acceptable level of financial sustainability of the program, under scenarios generated by assumptions on macroeconomic and investment condition. Projections are made through simulations adapted from a model developed by the Housing Finance Implementation Directorate Team, Ministry of Public Works and Housing of the Republic of Indonesia. The model can be used to simulate the financial balance conditions under certain scenarios (based on assumptions on macroeconomic and investment condition) and allocation policy mainly for fertilization and utilization. In addition, the model can also be used to analyze the number of participants in queues (waiting list for TAPERA's benefit) compare to number of beneficiaries.

In accordance with the provisions of the Government TAPERA participants are civil servants, military / police, private employees, and independent participants. The minimum wage for each worker is IDR $2,000,000$. The initial participation rate of civil servants in the first year was $4,468,000$ people with an estimated growth of $3 \%$ per year; TNI / Polri in the first year were 841,000 people and the growth rate of participants was $3 \%$ per year; the participation of private sector employees in the first year is $2.5 \%$ and the growth of subsequent participants $(4.00 \% ; 6.5 \% ; 7.5 \% ; 10 \% ; 20 \% ; 30 \%$; $40 \% ; 50 \%$ and; $60 \%$ ) and; for independent workers the first year membership is $2.5 \%$ and the following year participant growth is set to be the same as private employee participants.

Determination of the fixed income assumption for Tapera participants for the upper limit is IDR. 4 million and the lower limit is IDR. 2 million (minimum wage). Provisions on the determination of the amount of savings from workers $2.5 \%$ of income and $0.5 \%$ of employers, so that the total savings are set at $3 \%$ per participant per month. The increase in income of Tapera participants is assumed to be $6.0 \%$ per year and the basic salary is compared to the total income of $60 \%$.

To calculate the potential funds that can be collected from Tapera participants the assumption set is the saving rate (\% of expenditure) of households to income data based on deciles of $1-10(6 \% ; 9 \% ; 12 \% ; 15 \% ; 18 \%$; $21 \% ; 24 \% ; 27 \% ; 32 \%$ and; $42 \%$ ). In addition, it is necessary to establish the assumptions of potential Tapera participants who are actually Tapera participants. This is to find out conditions that are close to actual, so that the level of participation does not deviate too far from the target set. The 
mobilization rate for participants in $1-10$ is estimated at $30 \% ; 40 \% ; 50 \% ; 60 \%$ and in 5 to 10 years $70 \%$.

This study analyzes the sustainability of the TAPERA program based on simulation data generated by the above model. This analysis uses the indicators used in the model above, namely indicators on the financial aspects (deficit / surplus) and participation (number of beneficiaries, number of queues). The development of the two indicators is analyzed in relation to see the potential trade-off (disharmony) between the above two aspects. With this potential tradeoff, approaches and policies are elaborated that are needed to ensure harmonization or mitigate the impact of trade-offs between savings aspects and the use of deposits by TAPERA participants to own housing.

To calculate the tendency of TAPERA fund fertilization results, 3 approaches are applied, namely optimistic, moderate and pessimistic. These three conditions are specifically influenced by the dynamics of financial market conditions. Taking into account these conditions, the trend of yield conditions will then be seen; investment interest and costs (up, stagnant, down).

\section{$4 \quad$ Results and Discussion}

\subsection{Potential TAPERA Participants and Deposit Accumulation}

Some of the assumptions above are then used to calculate the potential funds that can be mobilized into TAPERA. The calculation of the potential for TAPERA funds is done through simulations with a conceptual framework that has been created, compiled, and prepared in a model and added calculation formulations that make it easy to project quantities that can be collected within a certain period. The results of the calculation of projections for the next 10 years produce figures as in Table 1 below.

Table 1. Calculation Results for TAPERA Participant Projections and Accumulated Deposits

\begin{tabular}{cccc}
\hline No & Amount & Total Deposits / month & Total Deposits / Year \\
\hline 1 & $6.733 .395,33$ & IDR 505.614.730.331,03 & IDR 4.550.532.572.979,25 \\
2 & $7.765 .898,15$ & IDR 583.361.055.378,90 & IDR 11.550.865.237.526,10 \\
3 & $9.437 .082,38$ & IDR 708.992.694.996,58 & IDR 20.058.777.577.485,00 \\
4 & $10.274 .978,28$ & IDR 771.973.873.177,51 & IDR 29.322.464.055.615,10 \\
5 & $12.053 .744,25$ & IDR 905.693.519.294,83 & IDR 40.190.786.287.153,10 \\
6 & $18.542 .608,09$ & IDR 1.393.539.622.885,72 & IDR 56.913.261.761.781,70 \\
7 & $25.274 .433,59$ & IDR 1.899.653.372.206,35 & IDR 79.709.102.228.258,00 \\
8 & $32.255 .928,99$ & IDR 2.424.539.195.498,37 & IDR 108.803.572.574.238,00 \\
9 & $39.493 .959,37$ & IDR 2.968.713.318.254,92 & IDR 144.428.132.393.297,00 \\
10 & $46.995 .549,80$ & IDR 3.532.703.996.995,49 & IDR 186.820.580.357.243,00 \\
\hline
\end{tabular}

Source:Simulation calculation results 
The number of TAPERA participants as presented in Table 1 above uses the approach of determining workers who are considered most likely to be Tapera participants and have great potential to join as participants in the following years. After a selective analysis of TAPERA participants, it can be determined that the most likely and most potential TAPERA participants to join Tapera participants are Formal Workers, TNI / Polri, Civil Servants, Private Workers, and Independent Workers. By using the assumptions as stated above, a potential Tapera fund deposit can be mobilized for the next ten years, both monthly and yearly (see Table 1).

\subsection{Potential for TAPERA Fund Fertilization}

The number of TAPERA participants as presented in Table 1 above uses the approach of determining workers who are considered most likely to be TAPERA participants and have great potential to join as participants in the following years. After a selective analysis of TAPERA participants, it can be determined that the most likely and most potential TAPERA participants to join TAPERA participants are Formal Workers, TNI / Polri, Civil Servants, Private Workers, and Independent Workers. By using the assumptions as stated above, a potential TAPERA fund deposit can be mobilized for the next ten years, both monthly and yearly (see Table 1).

Table 2. Interest Rates for State's Bank Time Deposits

\begin{tabular}{ccccc}
\hline \multirow{2}{*}{ Bank Name } & 1 Month & \multicolumn{2}{c}{ Percentage (\%) } \\
& 3 Months & 6 Months & 12 Months \\
\hline Mandiri & 3,7 & 6,2 & 5 & 4,5 \\
BNI & 5,1 & 5,8 & 5,5 & 5,3 \\
BRI & 5,5 & 5,8 & 5,8 & 5,8 \\
BTN & 6,3 & 6,3 & 6 & 5,9 \\
\hline \multicolumn{2}{l}{ Source: Bank Indonesia Money Market Information Center (PIPU), updated $15 / 11 / 2019$}
\end{tabular}

Table 3. Interest Rates for Private Bank Time Deposits

\begin{tabular}{ccccc}
\hline \multirow{2}{*}{ Bank Name } & \multicolumn{4}{c}{ Percentage (\%) } \\
& 1 Month & 3 Months & 6 Months & 12 Months \\
\hline BCA & 4,5 & 4,5 & 4,5 & 4,6 \\
CIMB Niaga & 6,1 & 6,6 & 6,3 & 6,3 \\
DANAMON & 5,6 & 5,6 & 5,6 & 5,6 \\
Bank Mega & 5,9 & 6 & 6,44 & 4,9 \\
\hline Source: Bank Indonesia Money Market Information Center (PIPU), updated 15/11/2019
\end{tabular}

For the Savings Bank Interest Rate, based on sources from the Panin Sekuritas Research Team, to date it has only been able to provide an average yield of $2 \%$ per year. There are three types of scenarios that can be developed 
in a TAPERA fund fertilization simulation, namely an optimistic scenario, a moderate scenario and a pessimistic scenario.

In an optimistic scenario, this scenario refers to the development of the Bank's debt and deposit interest market, which has a significant upward trend. Table 4 shows the yield rate of $7.37 \%$ with a tenor of more than 20 years and cash yield (Deposits) of $6.60 \%$, this figure will provide yields and investment interest which each year experiences increasing growth quite significant until the tenth year almost reached the 8,000 line and experienced a significant surplus (see Figure 2).

Table 4. Assumptions on interest rates and Optimisic Yields

\begin{tabular}{lcc}
\hline \multicolumn{1}{c}{ Interest Rate/yield } & Assumption & Descriptions \\
\hline Fertilization Rate & $7,37 \%$ & Bond/SUN rate \\
Deposit Yield & $3,00 \%$ & Tapera interest rate \\
Securities from channeling banks (for utilization: & $1,76 \%$ & Tapera loan rate \\
Interest Income) & & \\
Cash Returns (Time deposit): Reserved fund & $6,60 \%$ & Bank deposit rate \\
Land yields & $0,00 \%$ & Land Return Rate \\
Bank fees (including margin) & $3,24 \%$ & Bank Margin \\
Marjin SMF & $0,00 \%$ & SMF Margin \\
KPR (All-in Rate) & $5,00 \%$ & KPR Interest \\
\hline
\end{tabular}

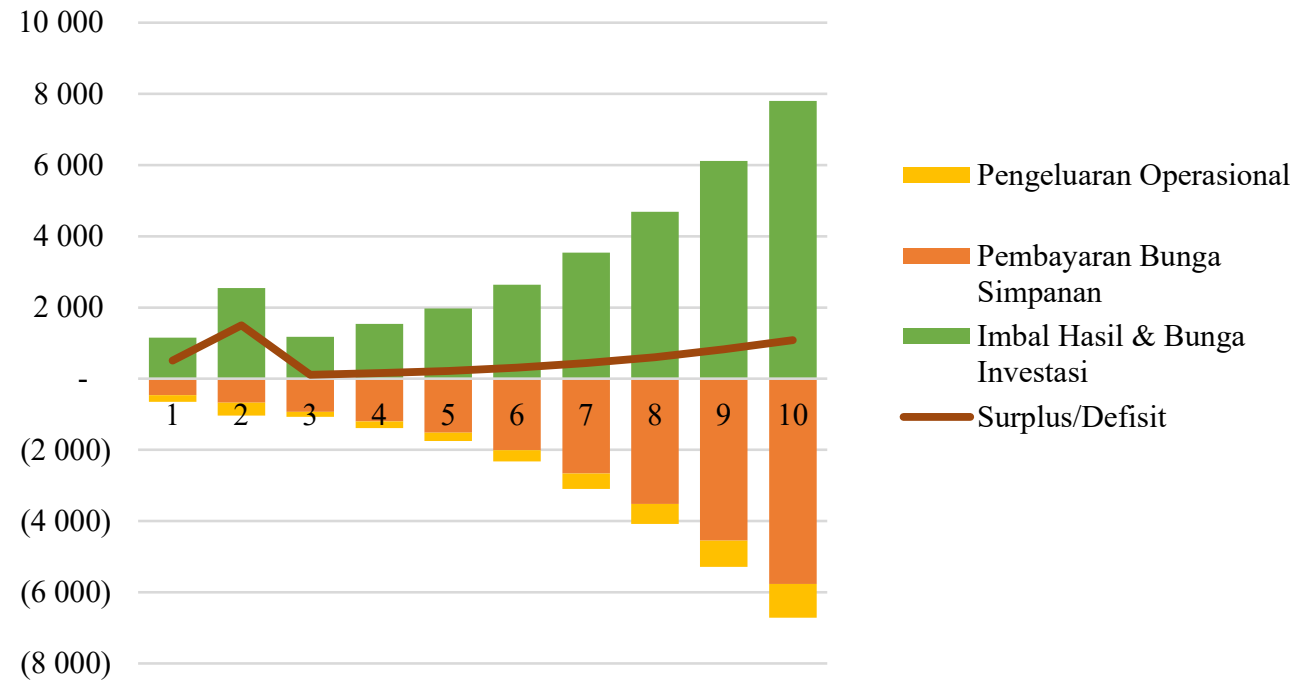

Figure 2. TAPERA Optimistic Sustainability

Furthermore, the moderate scenario, this scenario also refers to the development of the bond / bond market and the interest rate of Bank Deposits whose trend is not too high. 
Table 5 shows the Fertilization Rate (Bond Rate) of $6.50 \%$ with a tenor of 5 years and cash yields (Deposits) of 3.70\%. This figure will provide yields and investment interest which each year experiences increased growth that does not increase too significant until the tenth year it almost reached the outline of 7,000 and experienced a surplus that was not too significant (Figure 3).

Table 5. Assumptions on Interest Rates and Moderate Yields

\begin{tabular}{lcc}
\hline \multicolumn{1}{c}{ Interest rate/yield } & Assumptions & Descriptions \\
\hline Fertilization Rate & $6,50 \%$ & Bond/SUN rate \\
Deposit Yield & $3,00 \%$ & Tapera interest rate \\
Securities from channeling banks (for & $1,76 \%$ & Tapera loan rate \\
utilization: Interest Income) & & \\
Cash Returns (Time deposit): Reserved & $3,70 \%$ & Bank deposit rate \\
fund & & \\
Land yields & $0,00 \%$ & Land Return Rate \\
Bank fees (including margin) & $3,24 \%$ & Bank Margin \\
Marjin SMF & $0,00 \%$ & SMF Margin \\
KPR (All-in Rate) & $5,00 \%$ & KPR Interest \\
\hline
\end{tabular}

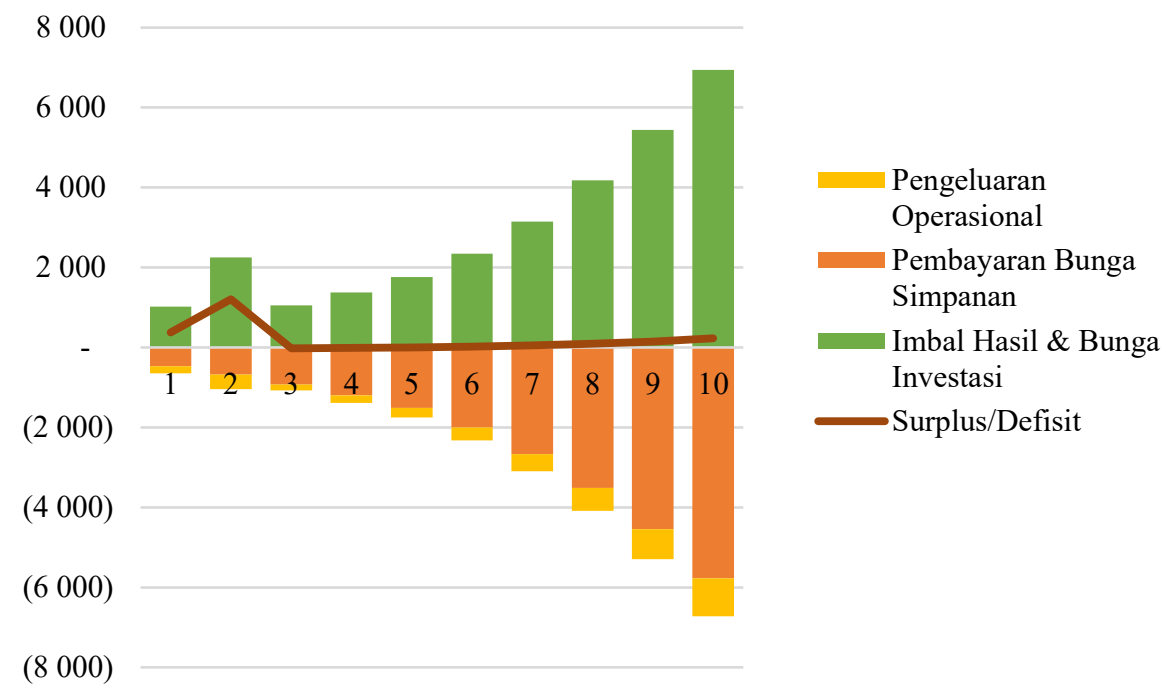

Figure 3. TAPERA Moderate Sustainability

The final scenario is the Pessimistic Scenario, which is the worst possible scenario with a declining market development rate.

Table 6 shows the Fertilization Rate (Bond Rate) of $5.50 \%$ with a tenor of 5 years and cash yields (Deposits) of $3.00 \%$. This figure will provide yields and investment interest which each year experiences a fairly declining growth 
significant until the tenth year it reaches roughly outlined (500) and experiences a significant deficit (Figure 4).

Table 6. Assumptions on Interest Rates and Pessimistic Yields

\begin{tabular}{lcc}
\hline \multicolumn{1}{c}{ Interest rate/yield } & Assumptions & Descriptions \\
\hline Fertilization Rate & $5,50 \%$ & Bond/SUN rate \\
Deposit Yield & $3,00 \%$ & Tapera interest rate \\
Securities from channeling banks (for & $1,76 \%$ & Tapera loan rate \\
utilization: Interest Income) & & \\
Cash Returns (Time deposit): Reserved fund & $3,00 \%$ & Bank deposit rate \\
Land yields & $0,00 \%$ & Land Return Rate \\
Bank fees (including margin) & $3,24 \%$ & Bank Margin \\
Margin SMF & $0,00 \%$ & SMF Margin \\
KPR (All-in Rate) & $5,00 \%$ & KPR Interest \\
\hline
\end{tabular}

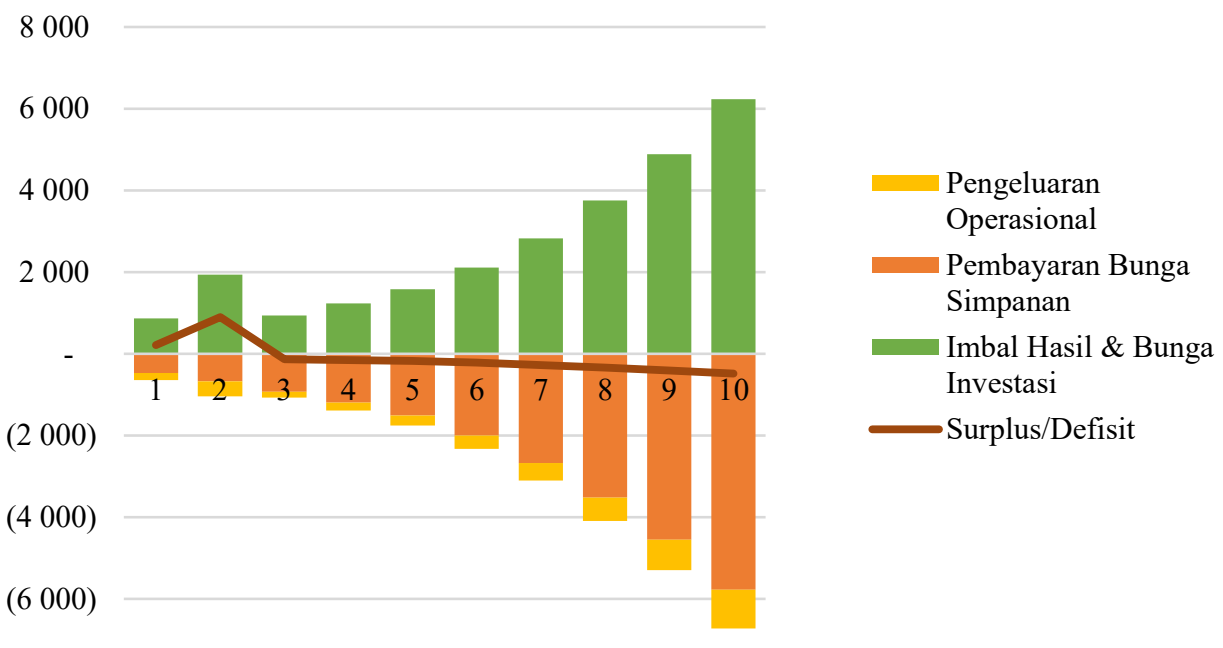

(8 000)

Figure 4. TAPERA Pesimistic Sustainability

Besides being influenced by the movement of the two components, namely the level of fertilization yields and cash yields (Deposits), the three scenarios are also inseparable from the effect of changes in expenditure components such as return on deposits given to TAPERA participants in the form of interest on TAPERA Deposits or expenses in the form of charges such as Bank fees.

Likewise, the income received outside the level of the results of fertilization and cash returns (Deposits) will affect the movement of the three 
scenarios, such as Securities from the Distribution Bank (for Utilization: Interest Income), namely the income received from loans provided.

Changes in the greater expenditure will reduce the returns received so that the graph tends to decrease and experience a deficit (Pessimistic Scenario). Likewise, the greater changes in income will make the received returns increase and the graph will be more likely to rise towards a surplus (Optimistic Scenario).

\subsection{Utilization Allocation}

In the Bond Rate scenario and the highest to lowest interest rates, with an allocation rate of $15 \%$ utilization, the condition of TAPERA funds until the 10th year continues to experience a surplus. In the Bond Rate scenario and the highest interest rates to the lowest, with a utilization rate of $25 \%$, the condition of TAPERA funds until the 10th year remains in a surplus. In the Bond Rate scenario and the highest interest rates to the lowest, with a utilization rate of $35 \%$, the condition of Tapera funds until the 10th year remains in a surplus. In the Bond Rate scenario of $5.30 \% ; 5.10 \%$; and $4.90 \%$ and interest rates of $2.86 \%$; $2.66 \%$; and $2.26 \%$ with a level of allocation of utilization of $55 \%$, the condition of TAPERA funds from year 3 to year 10 continues to experience a deficit.

In the Bond Rate scenario of $6.50 \%-4.9 \%$ and an interest rate of $3.70 \%$ - $2.46 \%$, with an utilization rate of $65 \%$, the condition of TAPERA funds from year 3 to year 10 continues to experience a deficit. In the Bond Rate scenario of $6.85 \%-4.9 \%$ and an interest rate of $4.86 \%-2.46 \%$, with a $70 \%$ utilization rate allocation, the condition of Tapera funds from year 3 to year 10 continues to experience a deficit. In the Bond Rate scenario of $7.37 \%-4.9 \%$ and an interest rate of $6.60 \%-2.46 \%$, with a $75 \%$ utilization rate, the condition of TAPERA funds from year 3 to year 10 continues to experience a deficit. In the Bond Rate scenario of $7.37 \%-4.9 \%$ and interest rates of $6.60 \%-2.46 \%$, with an utilization rate of $85 \%$, the condition of TAPERA funds from year 3 to year 10 continues to experience a deficit.

\subsection{Potential Use of TAPERA Funds}

Basically, the potential for large utilization (including beneficiaries) is highly depend on the allocation of utilization to the overall TAPERA Fund. The amount of utilization funds increase every year under an assumption that there is an increase in the number of participants each year, as well as ongoing participant contributions (no traffic).

The growth in the amount of utilization fund does not depend on utilization allocation. In the 10-year period, the average amount of utilization funds grows above 30 percent every year. The number of beneficiaries per year 
according to the percentage of utilization allocation, along with the cumulative amount. The number of beneficiaries increased in line with the increase in utilization fund allocation.

The growth of the number of beneficiaries per year does not depend on the size of the allocation of utilization. After recording negative growth in the 3 rd year, starting in the 4th year the growth is positive and continues to increase until the 5th year. Starting in the 7 th year the growth in the number of beneficiaries has decreased until the 10th year.

\subsection{Potential TAPERA Fund Reserves}

In the simulation model of TAPERA fund optimization, the potential of TAPERA fund reserves is obtained through the determination of the amount of deposits in advance. The accumulation of deposits is obtained from the BAPERTARUM Fund, the TAPERA Fund, and the Participant Return Reserves. In the balance sheet these components are included in the category of obligations. As stated in the slide at the beginning of the year, the amount of savings that can be collected amounts to IDR 15,678 trillion.

Funds collected in the savings account (liability) are then allocated according to the specified portion, namely $35 \%$ utilization, $60 \%$ fertilization and $5 \%$ reserves. The simulation results of the TAPERA fund optimization model based on each of the allocations that have been set, the TAPERA fund reserves can be projected for the next 10 years. The figure of IDR 11.505 trillion was obtained from TAPERA savings, namely the sum of the previous year's savings of IDR 4,551 trillion minus return of deposits (total savings) and return of deposits (fertilization results). Whereas the allowance for participant benefits is obtained from fertilization, which continues to increase each year.

\subsection{Determination of Critical Figure}

The critical figure factor of TAPERA funds is principally influenced by fertilization and utilization. The fertilizing factor will be influenced by the magnitude of the interest rate and yield. Whereas the utilization of critical conditions is influenced by the amount of utilization funds and their impact on the queue.

4.5.1. Fertilization Factor

If the assumption of interest rates and yields is optimistic, then since the beginning of the first year, the condition of fertilization results continues to show a positive trend. However, when applying moderate interest rate and yield assumptions, in the third and fourth years the condition of the TAPERA fund account experienced a deficit and increased slowly in the fifth year and so on. 
Whereas when applying pessimistic interest rate and yield assumptions, the financial account condition of TAPERA funds is only a surplus in the first and second years, and then in the third to tenth years continues to experience a growing deficit.

\subsubsection{Utilization Factors}

A critical aspect that needs to be explored in the TAPERA Fund program is the burden of the number of queues, ie participants who have not yet benefited. In this case the development of the number of queues should be balanced with the development of the number of beneficiaries. The following tables show that the growth in the queue of participants tends to be higher than the growth of beneficiaries, while the space for increased allocation of utilization is relatively narrow.

The development of participants according to categories (PNS, TNI / POLRI, Private, and Independent) continues to increase every year with an average gTrowth of 24.7 percent annually. With the participant development data above, and seeing the development of the number of beneficiaries, then we can calculate the (cumulative) development of the number of queues.

Meanwhile, the growth of the accumulation of the number of queues shows fluctuations in the first 6 years, and then tends to decrease starting with the 7 th year. This picture is seen in each utilization allocation option. If we compare this to the growth in the number of beneficiaries, it appears that in general the growth in the number of queues is slightly above the growth in the number of beneficiaries. This shows that there is a symptom of increased utilization which has not sufficiently offset the development of the queue (participants). This symptom is that the development of the ratio between beneficiaries to queues does not show a significant increase.

Meanwhile, space for increasing utilization is relatively narrow. Increase the utilization allocation above 65 percent (in this case 70 percent), we will face a deficit in the management of the TAPERA Fund. (See Tabel 8) 
Table 8. Developments of deficits / surpluses in the management of the TAPERA Fund According to Utilization Allocation (Billion IDR)

\begin{tabular}{cccccrrrrrr}
\hline $\begin{array}{c}\text { Allocation } \\
(\%)\end{array}$ & $\mathbf{1}$ & $\mathbf{2}$ & $\mathbf{3}$ & $\mathbf{4}$ & \multicolumn{1}{c}{$\mathbf{5}$} & $\mathbf{6}$ & $\mathbf{7}$ & $\mathbf{8}$ & $\mathbf{9}$ & $\mathbf{1 0}$ \\
\hline 15 & 446,5 & $1.836,0$ & 705,2 & 939,6 & $1.221,5$ & $1.648,4$ & $2.232,1$ & $2.984,3$ & $3.917,0$ & $5.042,1$ \\
25 & 446,5 & $1.739,3$ & 570,6 & 763,3 & 995,8 & $1.347,2$ & $1.827,8$ & $2.448,2$ & $3.218,8$ & $4.150,3$ \\
35 & 446,5 & $1.642,5$ & 436,0 & 587,0 & 770,1 & $1.046,0$ & $1.423,6$ & $1.912,1$ & $2.520,6$ & $3.258,4$ \\
45 & 446,5 & $1.545,7$ & 301,4 & 410,7 & 544,4 & 744,7 & $1.019,3$ & $1.376,0$ & $1.822,5$ & $2.366,6$ \\
55 & 446,5 & $1.449,0$ & 166,8 & 234,3 & 318,7 & 443,5 & 615,1 & 839,9 & $1.124,3$ & $1.474,8$ \\
65 & 446,5 & $1.352,2$ & 32,2 & 58,0 & 93,0 & 142,3 & 210,9 & 303,8 & 426,1 & 582,9 \\
70 & 446,5 & $1.303,8$ & $(35,1)$ & $(30,2)$ & $(19,8)$ & $(8,3)$ & 8,7 & 35,7 & 77,0 & 137,0 \\
75 & 446,5 & $1.255,4$ & $(102,4)$ & $(118,3)$ & $(132,7)$ & $(158,9)$ & $(193,4)$ & $(232,3)$ & $(272,1)$ & $(308,9)$ \\
85 & 446,5 & $1.158,7$ & $(236,9)$ & $(294,6)$ & $(358,4)$ & $(460,1)$ & $(597,6)$ & $(768,4)$ & $(970,3)$ & $(1.200,7)$ \\
\hline
\end{tabular}

Source: author's calculation

\section{Conclusion}

Under the optimistic scenario, allocation of $65 \%$ utilization and $35 \%$ fertilization is optimal in terms of beneficiaries covered, as well as in maintaining TAPERA's surplus along the 10 years period. It means that under the same scenario, any utilization allocation level exceeds $65 \%$ will bring TAPERA into deficit within the period.

At $65 \%$ utilization, deficit will also be there under the moderate and pessimistic scenarios. Under moderate scenario, TAPERA will experience deficit in the third and fourth years, and then slowly recover into surplus in the fifth year and so on. Meanwhile, under pessimistic scenario TAPERA will experience surplus in the first and second years, and after that continues to experience a growing deficit.

For any given allocation options, the growth of the accumulation of the number of queues shows fluctuations in the first 6 years, and then tends to decrease starting with the 7 th year. This figure is slightly above the growth of the number of beneficiaries. This shows that there is a symptom of increased utilization which has not sufficiently offset the participants in queue. It is reflected on the ratio between beneficiaries to queues that does not show a significant increase. The condition is coupled with relatively narrow space to increase the allocation of utilization, as TAPERA will experience deficit once the allocation exceed $65 \%$.

From the above, sustainability challenge of TAPERA will depends on the number and saving rate of participants, allocation policy, and financial market condition. The simulation results show that the acceptable figures of interest 
rate and yield that will maintain sustainability of TAPERA in the long run are at a minimum position of $3.7 \%$ and $6.50 \%$, respectively.

The tendency of increasing the number of participants in the future that will lead to increase TAPERA burden in the form of the queue-beneficiaries gap. This gap can be addressed by increasing the amount of savings, breakthrough in investment, or the government's subsidy. 


\section{References}

[1] Norizan Rameli et al. 2019. Housing Programmes And Urbanization: A Comprehensive Literature. Journal of Techno Social Vol. 11 No. 2 (2019) p. 17-23.

[2] Abdel Raheem et al. 2020. Analyzing affordable housing programs and projects in Egypt in the light of the positives of global experiences. Journal of Modern Research 2 (2020) 66-83.

[3] Henriko Ganesha Putra, et al. 2019. Tabungan Perumahan Rakyat (Tapera) Dan Penerapannya di DKI Jakarta. Jurnal Muara Sains, Teknologi, Kedokteran, dan Ilmu Kesehatan Vol. 3, No. 2, October 2019: 321-332. ISSN-L 2579-6410.

[4] Wahyudi, N. L. 2019. Optimizing of Public Housing Financing Policies for Low Income Community in Indonesia: Conceptual Approach. Archives of Business Research, 7(1), 230-244. DOI: $10.14738 /$ abr.71.5982.

[5] Saidu, Aliyu Ibrahim and Yeom, Chunho. 2020. Success Criteria Evaluation for a Sustainable and Affordable Housing Model: A Case for Improving Household Welfare in Nigeria Cities. Sustainability 2020, 12, 656; doi:10.3390/su12020656.

[6] Anacker, Katrin B. (2019) Introduction: housing affordability and affordable housing, International Journal of Housing Policy, 19:1, 1-16, DOI: 10.1080/19491247.2018.1560544.

[7] Suryanto et al. Analysis of Housing Finance Policies For Low-Income Community In West Bandung, West Java Province, Indonesia. Humanities \& Social Sciences Reviews, Vol 7, No 4, 2019, pp 1038-1045. eISSN: 2395-6518.

[8] A.O. Oyebanji et al. (2017). Critical Success Factors (CSFs) for achieving sustainable social housing (SSH). International Journal of Sustainable Built Environment 6 (2017) 216-227.

[9] Peer Smets \& Paul van Lindert. 2016. Sustainable housing and the urban poor, International Journal of Urban Sustainable Development, 8:1, 1-9, DOI: 10.1080/19463138.2016.1168825.

[10] Lulut Indrianingrum. 2016. Rencana Kepemilikan Rumah Bagi Masyarakat Berpenghasilan Rendah (Studi Kasus Kelurahan Tanjungmas Kota Semarang) Jurnal Teknik Sipil \& Perencanaan, Nomor 1 Volume 18 -Januari 2016, hal: 15 - 20.

[11] Martin Roestamy (2017). Providing Affordable Housing For Low-Income People In Indonesia (Development Of Model On Housing Law). IJASOS- International E-Journal of Advances in Social Sciences, Vol. III, Issue 9, December 2017.

[12] Undang-Undang Republik Indonesia Nomor 4 Tahun 2016 Tentang Tabungan Perumahan Rakyat.

[13] Undang-Undang Republik Indonesia Nomor 1 Tahun 2011 Tentang Perumahan dan Kawasan Permukiman.

[14] Undang-Undang U No. 13/2003 Tentang Tenaga kerja.

[15] Peraturan Bank Indonesia No.17/19/PBI/2015 tentang Perubahan Kedua Atas Peraturan Bank Indonesia Nomor 10/13/PBI/2008 Tentang Lelang dan Penatausahaan Surat Berharga Negara.

[16] Peraturan Pemerintah RI Nomor 78/2015 tentang Pengupahan.

[17] Fabozzi, Frank J. , Markowitz, Harry M. (Editors). 2002. The Theory And Practice Of Investment Management. John Willey \& Sons, Inc. Hoboken, New Jersey. Isbn: 0-471-228990 . 